\title{
Promoting English Independent Study for EFL University Students in Indonesia
}

\author{
Nina Inayati \\ The University of Muhammadiyah Malang, Indonesia
}

\begin{abstract}
This paper aims to investigate the implementation of English Independent Study (EIS) activities in English as a Foreign Language (EFL) educational contexts. In this study, 32 pre-intermediate to upper-intermediate participants attending a course named Basic Skill Course at an Indonesian university were introduced to the concept of and strategies for pursuing EIS. This investigation focused on analyzing the students' choice and perceptions of EIS activities and the continuity of the initiative. The findings show that students are more inclined to do receptive skill activities as opposed to those of productive skills for their EIS, students generally perceive EIS activities positively, and almost all students continued EIS activities on their own after they finished the semester. Some insights on how teachers could optimize students' motivation to do EIS activities are offered, such as providing extensive resources for independent study and devising various schemes to promote such activities among students.
\end{abstract}

One of the key aspects of globalization is the use of international languages as the means of communication among people from various countries. As one of the international languages formally recognized by the United Nations, English has gained increased acceptance as the primary means of international communication, indicated by the high number of nations which feature English as the main international language in their educational curricula (Crystal, 2003). Therefore, nurturing English skills among people in countries where English is considered a foreign language is essential. However, what often happens in English as a Foreign Language (EFL) contexts such as Indonesia and many other Southeast Asian and even Asian countries is that the teaching of English in school is not sufficient for students to speak English as well as expected (Soliman, 2014), and students' English proficiency often remains limited (Renandya, 2007). One way to address such problems is by introducing and supporting the habit of English Independent Study (EIS).

EIS offers a solution for the limited time and resources of English learning in the formal educational system by allowing and encouraging students to find authentic resources and integrate English learning into their daily activities. Studies have shown that independent learning is one of the key components of successful language learning (Wong \& Nunan, 2011; Yanren, 2007) and that students expect some independent learning strategies to be taught in classes (Luk, 2012). However, studies about nurturing independent study and its continuous impact have, to the author's knowledge, never been conducted. Therefore, the present study aimed to investigate efforts to introduce and foster such practice to two groups of Indonesian undergraduate students majoring in the English language. The purpose of the scheme was to promote continuous learning of English independent from the presence of the traditional

Language Education in Asia, 2015, 6(1), 46-57. http://dx.doi.org/10.5746/LEiA/15/V6/I1/A5/Inayati 
educational system and to encourage lifelong learning of English. This study specifically focused on analyzing the types of English independent study that students did, their perceptions of EIS, and the continuity of the EIS initiative after the semester finished.

\section{Second Language Acquisition}

\section{Literature Review}

Independent English study has its roots in the theory of second language (L2) acquisition. As theorized by Krashen (1982), L2 is acquired through significant exposure to the language from the environment in the form of authentic communication, much like the acquisition of the first language. This theory, which is also the basis of the Communicative Language Teaching (CLT) approach, is employed as the theoretical framework of the current study.

According to Krashen (1982), "language acquisition is a subconscious process-language acquirers are not usually aware of the fact that they are using the language for communication" (p. 10). The acquired competence, he further argued, is subconscious as well-making the understanding of the L2 rules "felt," instead of deliberately learned or known. This way, one would feel that grammatically correct sentences sound "right," and grammatically incorrect sentences sound "wrong," without necessarily knowing the exact reasons. This notion is in line with the theory of first language acquisition, one of the features of which is the rich exposure to the language from the environment, such as from the parents, siblings, relatives, friends, teachers, and media (Lightbown \& Spada, 2006). When applied to the teaching of a foreign language, one of the closest approaches resembling the idea of first language acquisition is EIS.

\section{English Independent Study (EIS)}

There have been a number of studies about independent study in English, a notion also commonly referred to as independent learning or autonomous learning (Luk, 2012). Smith (2008) defined autonomous learning as one's capacity to be in control of one's own learning. Therefore, in this study, EIS is defined as any student effort outside the classroom to improve the student's English skills, without specific instructions or assignments from a teacher. EIS requires students to find or create their own English exposure, thus maximizing their attempts for acquisition. This is especially true in EFL contexts, such as that in Indonesia and many Asian countries, where exposure to the language in the students' natural environment is limited. In EIS, students are expected to choose the materials or activities that they enjoy and which suit their level of English proficiency. Therefore, students should first be given training about how to choose appropriate materials and activities for their EIS. This is in line with Krashen's (1982) suggestion that English language teachers should provide not only the content or materials to study, but also the tools and strategies to help students to continue learning and improving beyond the boundary of the classroom. In EIS, such training is focused on helping students firstly to find potential English exposure in their immediate surroundings or to create their own English exposure, and secondly to do the activity effectively by considering some principles and strategies in conducting independent learning.

As explained by Crabbe (1993), autonomous learners learn in their minds, regardless of the place. He added that the success of language learning relies on how well students could make the best use of various learning opportunities both within and outside the classroom. In other words, in addition to classroom learning, students should be assisted in finding potential English exposure by improving their sensitivity to anything "English" around them. For example, English sensitivity could be developed by being more aware of things that contain English words, phrases, or sentences, such as the information on food packages, shop names and descriptions, advertisements, online materials, and TV programs. Meanwhile, creating English 
exposure could be achieved by introducing some English into one's daily life. For example, if a student enjoys listening to songs and his or her playlist consists only of non-English songs, he or she could add some English songs to it, and if a student attends a lecture or meeting and usually makes notes, he or she could write the notes in English.

In addition to finding and creating their own English exposure, students are encouraged to consider some principles and strategies of effective and efficient independent learning. Some principles of Extensive Reading could be applied to EIS, since Extensive Reading could be regarded as a form of independent study focusing only on reading, while EIS is an effort to extend the approach to all four language skills. Therefore, adopting some principles of Extensive Reading activities such as those proposed by Renandya (2007), Day and Bamford (2002), and Mikulecky and Jeffries (2007), EIS principles can be formulated as follows. First, high availability of resources is essential. Here, students should be encouraged to find or create as much exposure as possible and / or to do EIS activities as many times as they can. Students could be assisted to identify potential resources in their immediate environment, for example, English newspapers, TV programs, music, or texting or posting on social media in English. Second, students should freely choose materials and activities that interest them. This would likely ensure that those materials are personally enjoyable and relevant for them. Third, comprehensible language input and output is important. Students should choose materials or activities that are not too difficult nor too easy for them, and their EIS should be balanced between input (receptive skills) and output (productive skills). Fourth, various strategies to enhance EIS should be introduced. For example, students could be taught strategies to identify materials of suitable level of difficulty, such as the "five finger rule" (Mikulecky \& Jeffries, 2007, p. 4), in which if the first page of a book contains more than five unfamiliar vocabulary items, then it is too difficult for the student. Thus, the student can choose to read another book that is easier. Another strategy dealing with watching movies is to avoid local language subtitles. Students can try to watch a movie without subtitles, or if this is too difficult, they can set the subtitles to English. If they still find it too difficult, they can start by watching an easier genre of movies such as children's or animated movies, in which the language use is relatively simpler than that of science fiction or psychological thriller movies.

\section{Previous EIS Studies}

Independent study has often been correlated to successful language learning. Wong and Nunan (2011), for example, identified effective language learners as being independent and active in their learning approaches. Based in Hong Kong, their study involved one hundred and ten undergraduate students in Hong Kong. They were classified as "more effective" and "less effective" language learners based on their scores on a standardized public English examination administered at the end of secondary school. One of their findings suggested that a significantly longer time was spent by the more effective learners in independent study and in the practice of their English skills outside the class compared to that of the less effective learners. In addition, Chamot (2005) reviewed two studies about how the teaching of strategies could help foster independence among students. The first study reported students' positive remarks towards the usefulness of the training, while the latter study reported that the experimental group, who were explicitly trained in language learning strategies, performed significantly better in an English test than the control group.

An interesting study was conducted by Yanren (2007), who interviewed several winners of national English speaking and debate competitions in China. She found that these Chinese learners of English spent a great deal of time outside class learning English independently by imitating and memorizing dialogues from their favorite books and movies. Another study on 
EIS in EFL contexts was conducted by Luk (2012), who surveyed 45 students in a Japanese university to see if they did any form of independent study outside class. The findings showed that all students reported that they did some independent study activities outside the class to improve their English proficiency. The author then concluded that the study participants were generally willing to spend some time outside the class time to learn English and that they need more guidance in doing it effectively and successfully.

\section{Methodology}

This study employed content analysis and a survey to analyze the types of English independent study that the participants did, their perception of EIS and the continuity of the EIS initiative after the semester finished. Students' independent study weekly reports were analyzed to answer the first research question about the types of independent study activities that they did during the semester. For the second research question about the students' perception of the independent study activities during the semester, their end-of-semester reflection was employed as the data. Finally, a survey was used to probe the continuity of the independent study after the semester had finished. The survey items were mostly open-ended to allow the provision of un-influenced answers about the continuity of the activities, the benefits (if any), and the factors that facilitate or hinder independent study activities after the completion of the course (see the Appendix).

The participants in this study were students from two classes of the English Department in the vocational college of a public university located in Malang, East Java, Indonesia. The students' first language was Indonesian, and they had previously learned English mainly from high school. At the time of the study, their English proficiency level ranged from pre-intermediate to upper-intermediate (TOEIC scores of 350 to 650). They were the students of the 2013 enrollment year, and each class consisted of 16 students. There were 32 students in total, with 25 female and 7 male students, whose ages ranged from 18 to 20 years. At the time of the study, the students were in the second semester and were taking the Basic Skill Course (BSC) taught by the researcher. The course taught integrated skills at the intermediate level, involving all language skills and components, to prepare students for both advanced skill and content courses offered in the following semesters. This course began in February 2014 and lasted for 14 weeks until June 2014.

During the course, the students were introduced to the concept of English independent study in the first week and were then asked to try to do some EIS activities based on their interests. The introduction involved a short lecture on how maximizing opportunities for language acquisition could assist second language learning and how students can implement this concept into their learning through EIS activities. Following the lecture, students were asked to brainstorm and discuss potential ideas about English exposure in their immediate environment. Some strategies and principles on how to find EIS materials and activities were given, such as those proposed by Luk (2012), Yanren (2007), Renandya (2007), Day and Bamford (2002) and Mikulecky and Jeffries (2007). Next, students were encouraged to try different EIS activities every week, and they were to report the activities in a weekly EIS report for 12 consecutive weeks. At the end of the semester, the students were required to write a reflection paragraph about their EIS activities during the semester. Finally, the survey about the continuity of the students' EIS activities was administered in December 2014, six months after the semester had finished. At that time, the former Basic Skill Course students were not being taught by the researcher; thus, there was no direct influence from the researcher on the students regarding EIS activities. 
The data collected were then analyzed using content analysis to identify themes and draw inferences. The analysis was conducted manually as the volume of the data was not high. The findings of the analysis are presented in the following section.

\section{Findings}

\section{Types of EIS Activities}

In total, there were 32 weekly reports collected by the end of the semester; each, if completed, contained 12 EIS activities conducted by the students. However, some absent students chose not to report their EIS activities in the weeks they missed, thus some reports contained less than 12 activities. The analysis of the reports shows that receptive skills (reading and listening) are higher in popularity than the productive skills (writing and speaking). The most common skill that students pursued for EIS was reading, followed by listening, while writing and speaking activities were less commonly employed by the students. Figure 1 illustrates students' EIS activities as shown per skill and the respective frequency of occurrence in the students' weekly reports.

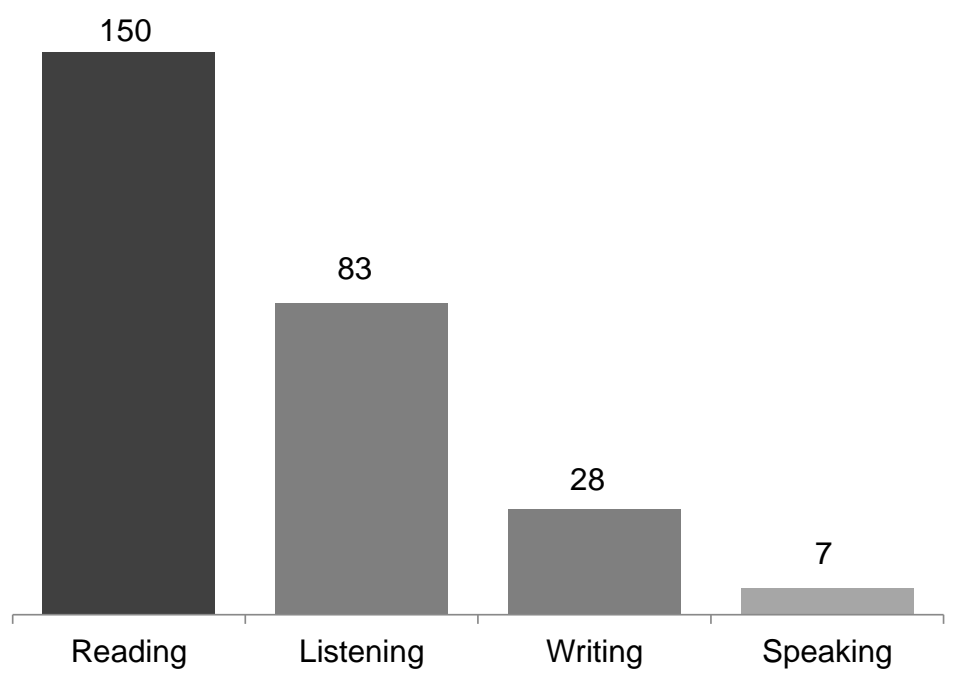

Figure 1. Number of EIS activities by skill done by the students during the semester

Looking further into the details of the EIS activities noted by the students in their weekly reports, the most popular activities were listening to English-language songs (34 references), reading articles in English (33), and watching English-language movies (32 references). The second most popular activities were reading English-language books or novels (18 references), reading posts in English on social networking sites (16 references), playing computer games with instructions in English (13 references), and reading posts on social media sites such as blogs and Tumblr (10 references). There are 39 other activities found with a relatively lower popularity, indicated by the references of less than 10. These activities included reading newspapers, writing social media posts in English, speaking with friends in English, watching Englishlanguage television programs, texting in English, and learning from the BBC website.

\section{Student Perceptions of the EIS Activities}

Both positive and negative perceptions about independent study were found in the students' end-of-semester reflections about their EIS activities. In general, however, the students perceived the activities positively; there were 45 references for positive perceptions and only four references for negative perceptions. For the positive perceptions, the most mentioned 
benefits were that EIS was helpful in enriching their English vocabulary (17 references), and effective in improving general English skills (ten references). In addition, some students reported that it helped them to see their old habits anew (two references), such as learning English from listening to songs or writing social media posts. There were seven other benefits which represented positive perceptions, each referred to by one student, and they were: it raised awareness to study harder, it was a useful activity, it helped learning new knowledge, it helped to increase speaking skills, it helped to make a new and educative hobby, it was challenging, and it helped learning by oneself. Below are selected student comments.

I think when I did things, it's useless, but now I find it interesting. So when I listen and watch something, I do it carefully to find unfamiliar words. I feel more clever as they are useful in class. (Student 14, Class B)

It's a good way to study English well, because after I wrote the words, I also know how to use it. (Student 6, Class A)

As for the negative perceptions, two students thought that EIS was difficult, one student thought it was not really effective, and the final student thought it was confusing at first but then said that it was challenging.

In addition, the impact of EIS was found to go beyond language learning. One student noted that EIS helped her to spend her time more usefully by turning everyday activities into opportunities to learn English. She deliberately tried to learn some English vocabulary when she watched movies and put the language setting of her accounts in English. Another student reported that EIS also trained her to be more honest. This was because she did EIS independently and if she chose to be honest and really did it, she would reap the benefits for her English language learning. However, if she reported something she did not actually do in the weekly report, she was aware that she would not benefit from it.

\section{Continuity of the EIS Activities}

At the end of the next semester, the former students of the BSC course were invited to complete a survey about the continuity of their EIS. At this time, 25 out of 32 students participated in the survey; three were male and 22 were female. The students were asked if they found the independent study training in the previous semester useful. All of them found it useful, with a bit of variation in the degree of usefulness: 15 thought it was useful, eight thought it was very useful, one thought it was somewhat useful, another thought it was less useful, and no one thought it was useless.

When asked about whether they continued some EIS activities discussed and tried in the previous semester, $96 \%$ of the students reported that they did, with only one student saying no. The students who reported continuity were then asked about the types of EIS activities that they did and the frequency of doing them. An analysis of the answers showed that the types of the EIS activities they did were somewhat similar to what they did during the semester in that receptive skill activities were more frequently mentioned compared to those of productive skills. It was found that activities related to listening were the most commonly chosen, followed by various reading activities. Not far in popularity from reading were the writing activities and finally, speaking activities and integrated English activities were the lowest in popularity. Figure 2 displays the types of EIS activities that students did six months after the semester ended and the number of references to the activities. 


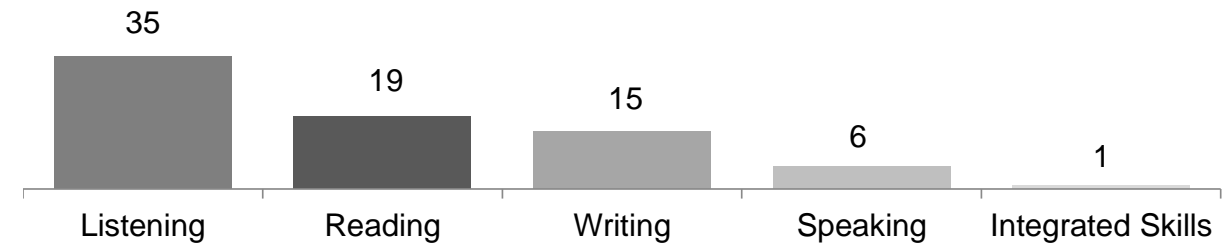

Figure 2. Number of EIS activities by skill done by the students after the semester finished

The questionnaire probed the affordances and barriers of doing EIS activities. Some factors reported to support the students' EIS activities were the fact that they liked listening to music (nine references), watching movies (seven references), reading articles (three references) and reading books / novels (two references). These hobbies that they used to enjoy in their native language were turned into English learning by, for example, listening to English songs, watching western movies with English subtitles or no subtitles at all, and reading articles and books or novels in English. Other factors that students reported as affordances were, for example, that they wanted to get good scores in their studies, they felt motivated when seeing people talking in English fluently, they had specific targets for their English proficiency, they wanted to speak with people from other countries confidently, and they wanted to increase their knowledge. These factors served as the drive that motivated them to initiate EIS activities.

Students reported the biggest factor that hindered them from doing EIS activities was laziness (nine references). The second most mentioned factor was limited time (seven references); they reported that time-consuming activities, such as doing course assignments and student organization activities, prevented them from doing EIS activities more frequently. Other factors that served as barriers include distraction (e.g., other activities not related to English) and lack of funds to buy English materials such as books or novels.

\section{Discussion and Implications}

The EFL environment presents a unique challenge in that exposure to the language is limited. However, this study found that such exposure is available if learners are assisted to create more awareness. In general, this study found that most participants were in favor of EIS activities during the semester and almost all of them continued the activities in various forms and degrees after they finished the semester. The participants in this study showed some qualities of autonomous learners in that, as pinpointed by Crabbe (1993), they were able to make use of some learning opportunities inside and outside the classroom. In addition, like the students in Yanren's (2007) study, the EIS activities chosen by the participants in this study were those that they personally enjoyed, such as reading and watching movies. Looking further into the types of EIS activities done by the participants, they somewhat reflect Luk's (2012) study in that receptive skills are more popular in comparison to productive skills. Furthermore, many similarities were also found in the details of the EIS activities for each skill. This similarity may 
be because both studies were conducted in EFL environments—one in Japan and the current study in Indonesia.

A slightly different result in types of EIS activities reported by the participants during and after the semester was found. During the semester, reading activities were the most popular EIS activities, but after the semester finished, listening / viewing activities were the most popular ones. Looking deeper into the data, the listening activities done by the participants were mostly listening to songs and watching movies, relatively popular hobbies among teenage students, which could be one of the reasons for the shift. Another possible reason is that there was no push for them to vary their EIS activities as there was during the semester when they were encouraged to do different activities each week. In other words, without any interference, students may find listening / viewing activities to be the most enjoyable EIS activities.

The relatively large discrepancy between productive and receptive skills in the types of EIS activities done by the participants should be of deeper concern for English language teachers. Analysis of the EIS activities conducted during and after the semester shows that the receptive skills practiced, such as reading and listening / viewing are more popular than productive skills such as writing and speaking. This may be because productive skills require relatively more effort than receptive skills. However, in learning a new language, both input and output should be balanced. As Nation (2007) suggested, effective L2 learning should balance several issues, two of which are input and output. To address the imbalance, teachers could introduce measures to motivate students to do both productive and receptive skills in equal proportions. One way to do this is by teaching more strategies to do writing and speaking activities independently and by integrating such activities into students' daily activities. For example, they can be encouraged to develop an English-speaking policy schedule with siblings or friends, practice speaking alone regularly, or write daily notes in classes or in meetings in English. Another way is by establishing a speaking club or speaking corner where students could go to if they want to practice independently. In addition, it is important to note that after the semester, one student reported a new type of EIS activity involving integrated skill activity using an interactive website for EFL learners. This case could be viewed as an advancement in the student's EIS and, with regard to achieving balance between receptive and productive skills, such websites could be introduced to students as another means of EIS.

\section{Optimizing the Continuity of Students' EIS}

Almost all students reported that they continued the EIS activities on their own accord. This shows that the EIS training was reasonably successful in arousing students' awareness in creating their own exposure to English and in igniting students' initiative to learn English independently. However, it is understood that there are many factors that may influence students to do EIS activities independently, such as their level of motivation, the availability and accessibility of resources, and the potential hurdles that may block students from actually doing the activities. Understanding these factors could help teachers, institutions, and policy makers take measures to assist students' independent study initiatives.

Based on student reports of motivation, opportunities, and barriers, teachers and institutions could devise various methods to help increase students' motivation such as by exposing students to various contexts where English is needed and various opportunities in which they can use their English in meaningful ways. For example, by students creating an English club, sharing communities, or going on study excursions, they could experience firsthand the benefit of their EIS activities. In addition, to increase students' opportunities to do EIS activities, institutions could establish a self-access center containing English learning resources designed 
to support independent learning. Although some institutions have already established selfaccess centers, many institutions, such as that where this study was conducted, have not. Considering the benefit of independent study to students, a self-access center in addition to English programs is important, and the characteristics of learning resources that students enjoy could be used as a guide to select the materials and resources that could be provided in such centers. This center could also potentially solve students' problems of lacking self-funding to buy independent study resources. Finally, to overcome potential barriers such as time limitations, students could be encouraged to integrate their English learning into their everyday activities, thus reconsidering the common view that learning should be done at a particular time, such as during the class time. Some strategies to integrate learning through EIS into students' lives also need to be emphasized in EFL classes along with supervision from teachers before students actually try EIS activities by themselves in the future.

\section{Conclusion}

English Independent Study (EIS) was conceptualized as a solution to the problem of limited exposure to English in EFL contexts, to help students to be more aware of potential exposure around them and / or to create their own English exposure. This paper analyzes the implementation of EIS activities and their continued practice by the students after the training ended. It was found that students did various EIS activities with relatively high preferences to receptive skill training compared to productive skill training. The students generally perceived the EIS training positively and they also reported continuing EIS activities even after the semester finished. Some suggestions and principles to implement EIS were offered, for example, the teaching of strategies for EIS, the high availability of learning materials, and the freedom of students to choose resources of interest to them.

Some limitations of this study, such as the absence of discussion about the impacts of EIS training on students' English proficiency, or the single education level studied, could be a basis to guide further study in the area. Despite the limitations, this study still offers valuable insights for other EFL teachers and practitioners who work in ELT contexts with minimum resources as an alternative way to improve and maximize students' English language learning.

\section{Author Note}

Nina Inayati, English Department, the University of Muhammadiyah Malang, Malang, East Java, Indonesia.

Nina Inayati teaches English in the University of Muhammadiyah Malang, Indonesia. She has published three textbooks for English language teaching and a research paper in an international journal, and presented in several international ELT conferences. Her research interest is in technology and independent learning in ELT.

Correspondence concerning this article should be addressed to Nina Inayati, English Department of the University of Muhammadiyah Malang, Jl. Raya Tlogomas 246, Malang, East Java, Indonesia, 65144. E-mail: ninainayati@gmail.com 


\section{References}

Chamot, A. U. (2005). Language learning strategy instruction: Current issues and research. Annual Review of Applied Linguistics, 25, 112-130. http://dx.doi.org/10.1017/S0267190505000061

Crabbe, D. (1993). Fostering autonomy from within the classroom: The teacher's responsibility. System, 21(4), 443-452. http://dx.doi.org/10.1016/0346-251X(93)90056-M

Crystal, D. (2003). English as a global language. Cambridge, UK: Cambridge University Press.

Day, R., \& Bamford, J. (2002). Top ten principles for teaching extensive reading. Reading in a Foreign Language, 14(2), 136-141.

Krashen, S. (1982). Principles and practices in second language acquisition. Oxford, UK: Pergamon. Available from: http://www.sdkrashen.com/content/books/principles_and_practice.pdf

Lightbown, P. M., \& Spada, N. (2006). How languages are learned ( $3^{\text {rd }}$ ed.). Oxford, UK: Oxford University Press.

Luk, H. (2012). Independent learning for language students. Kwansei Gakuin University Humanities Review, 17, 59-67.

Mikulecky, B. S., \& Jeffries, L. (2007). Advanced reading power. New York, NY: Pearson Education.

Nation, P. (2007). The four strands. Innovation in Language Learning and Teaching, 1(1), 1-12. http://dx.doi.org/10.2167/illt039.0

Renandya, W. A. (2007). The power of extensive reading. RELC Journal, 38(2), 133-149. http://dx.doi.org/10.1177/0033688207079578

Smith, R. (2008). Learner autonomy. English Language Teaching Journal, 62(4), 395-397. http://dx.doi.org/10.1093/elt/ccn038

Soliman, N. A. (2014). Using e-learning to develop EFL students' language skills and activate their independent learning. Creative Education, 5, 752-757. http://dx.doi.org/10.4236/ce.2014.510088

Wong, L. C., \& Nunan, D. (2011). The learning styles and strategies of effective language learners. System, 39, 144-163. http://dx.doi.org/10.1016/j.system.2011.05.004

Yanren, D. (2007). Text memorization and imitation: The practices of successful Chinese learners of English. System, 35(2), 271-280.

http://dx.doi.org/10.1016/j.system.2006.12.005 


\section{Appendix \\ Survey on the Continuity of English Independent Study}

\section{Personal Information}

1. Which BSC class were you?

$\square$ BSC A

$\square$ BSC B

2. What is your sex?

$\square$ Male

Female

3. How old are you?

years old

4. What is your TOEIC score?

INSTRUCTION: Based on your real experience, please answer the question below. You are allowed to answer using either English or Bahasa Indonesia.

1. How useful was the information and training on English Independent Study you received during the BSC class last semester?

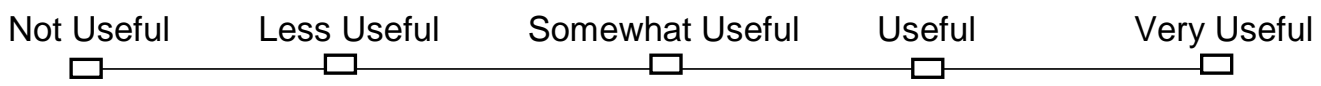

2. What English Independent Study activities that you still did after the class finished or even until the present time? And what about the frequency of the activities?*

\begin{tabular}{|l|l|l|l|c|}
\hline \multirow{2}{*}{ Independent Study Activities } & \multicolumn{4}{|c|}{ Frequency } \\
\hline & Seldom & Sometimes & Often & Very Often \\
\hline Example: listening to English songs & & & & $\mathrm{X}$ \\
\hline & & & & \\
\hline & & & & \\
\hline & & & & \\
\hline & & & & \\
\hline & & & & \\
\hline & & & & \\
\hline
\end{tabular}

Note: Seldom (less than once in a month), Sometimes (one to three times a month), Often (once a week or more), Very Often (everyday)

3. Do you think doing English Independent Study is useful for improving your English proficiency? If so, in what way?

$\square \mathrm{No}$, it is not useful.

$\square$ Yes, it is useful, for example ... (e.g., it adds my English vocabulary) 
4. In your personal context, what are the affordances (pendorong) and barriers (hambatan) of doing English Independent Study?

Affordances: (e.g., I love reading books, so I choose English books)

Barriers: (e.g., I am too busy with organization, I don't have time)

*If you need more space, you can continue behind the page. 